ISSN : 2356-3966

Vol.6 No.2

\title{
REAKSI PASAR MODAL TERHADAP PENGUMUMAN KEMENANGAN PRESIDEN JOKO WIDODO BERDASARKAN KEPUTUSAN KPU PEMILU PERIODE 2019-2024 (Studi pada Perusahaan BUMN yang Terdaftar Di BEI)
}

\section{Erica P. Akbar, Ivonne S. Saerang, Joubert B. Maramis}

Universitas Sam Ratulangi

A R T I C L E I N F O

Keywords: Event Study, Abnormal Return, and Abnormal TVA
Kata Kunci: Event Study, Abnormal Return, dan Abnormal TVA
Abstract : The capital market is one indicator of economic progress. Events affect the formation of stock price fluctuations. This research was conducted with the aim of knowing the Market Reaction to the announcement of victory, based on data on stock price movements 14 days before and after the event. This type of research is in the form of quantitative research using secondary data, returns and volume of share prices of SOE companies going public, then tested different paired samples test. The results showed that there were significant differences in Abnormal Return. That is, the market reacts to the Announcement of Victory, because stock price movements are still influenced by an information and events. Meanwhile, TVA Abnormal Indicator shows a unique result, there is no partial difference in abnormal trading activity but there is a significant difference in the combined ATVA test. Investors in SOE shares trust the value of SOE shares so that they are not easily affected by short-term information. However, in SOE stock transactions (combined TVA Abnormal Test), a fraction of the activities of panicked SOE Investor investors, as well as traders' activities, can be seen, so there are significant differences in the average Investor trading activity.

Abstrak: Pasar modal merupakan salah satu indikator kemajuan perekonomian. Gambaran keadaan politik mencerminkan keadaan pasar, sehingga mempengaruhi psikologi Investor dalam mengambil keputusan Investasi. Pasar Modal bereaksi terhadap peristiwa yang mengandung informasi. Peristiwa berpengaruh terhadap terbentuknya fluktuasi harga saham, misalnya peristiwa 22 Mei 2019. Penelitian ini dilakukan dengan tujuan untuk mengetahui Reaksi Pasar terhadap pengumuman kemenangan, berbasis data pergerakan harga saham 14 hari sebelum dan sesudah peristiwa. Jenis Penelitian yang digunakan berupa penelitian kuantitatif menggunakan data sekunder, return dan volume harga saham perusahaan BUMN go public, kemudian diuji beda paired samples test. Hasil Penelitian menunjukkan terdapat perbedaan Abnormal Return yang signifikan. Artinya, pasar bereaksi terhadap Pengumuman Kemenangan, dikarenakan pergerakan harga saham masih dipengaruhi oleh suatu informasi dan peristiwa. Sedangkan, indikator Abnormal TVA menunjukkan hasil yang unik, yaitu tidak terdapat perbedaan aktivitas perdagangan abnormal secara parsial namun terdapat perbedaan signifikan dalam uji ATVA gabungan. Investor pada saham BUMN mempercayai value saham BUMN sehingga tidak mudah terpengaruh informasi jangka pendek. Akan tetapi, dalam transaksi saham BUMN (uji Abnormal TVA gabungan), sebagian kecil aktivitas dari Investor saham BUMN yang panik, serta aktivitas trader, dapat terlihat, sehingga terdapat perbedaan yang signifikan pada rata-rata aktivitas perdagangan Investor. 


\section{PENDAHULUAN}

\section{Latar Belakang}

Pasar modal merupakan media investasi modal dengan cara membeli surat-surat berharga seperti saham ataupun obligasi. Pasar modal merupakan salah satu indikator kemajuan perekonomian negara, yang turut berperan serta menunjang perkembangan dan pertumbuhan ekonomi. Gambaran keadaan politik dalam suatu negara merupakan cerminan keadaan pasar modal, yang dapat mempengaruhi kepercayaan dan psikologi Investor dalam mengambil keputusan Investasi. Pasar Modal dapat bereaksi terhadap peristiwa yang mempunyai kandungan informasi, sehingga berpengaruh terhadap terbentuknya fluktuasi harga saham.

Suatu peristiwa, terkhususnya peristiwa politik semakin berkaitan erat dengan kestabilan perekonomian suatu negara, Di Indonesia sendiri pengaruh peristiwa politik sangat berkaitan dengan reaksi yang ditimbulkan dalam pasar modal, peristiwa tersebut antara lain: pemilihan umum Presiden (Pemilu), pemilihan Legislatif (Pileg), kerusuhan, peperangan dan peristiwa lainnya. Peristiwa- peristiwa ini berdampak pada kestablilan harga saham dan volume perdagangan di pasar modal. Oleh karena itu, gambaran keadaan politik dalam suatu negara merupakan cerminan keadaan pasar modal apakah stabil atau tidak, untuk dapat menjadi pertimbangan investor dalam menentukan pilihan berinvestasi. Jika keadaan politik dalam suatu negara stabil, maka keadaan ekonomi negara pun stabil, dan akan mendatangkan respon positif dari para Investor. Begitu pula sebaliknya, apabila peristiwa politik suatu negara dalam keadaan tidak stabil, stabilitas ekonomi menjadi terancam dan dapat mendatangkan respon negatif dari Investor.

Peristiwa pengumuman kemenangan presiden merupakan peristiwa ekonomi yang penting. Bukan hanya nasional, namun sebenarnya juga secara internasional. Karakteristik bakal pemimpin yang diumumkan menang, menjadi faktor penilaian serta tolak ukur bagi para investor dalam menilai optimisme pasar. Karakteristik pemimpin tercermin dari prestasi-prestasi dan keberhasilannya, yaitu rekam jejak dan histori pemimpin tersebut di masa lalu. Penilaian terhadap pemimpin inilah yang mempengaruhi Investor untuk memutuskan investasi di pasar modal secara merata, dimana salah satu instrument yang popular ialah saham. Ada 500 lebih saham yang kini tercatat di Bursa Efek, maka dari itu penulis memilih perwakilan dari saham dan pasar modal yaitu perusahaan BUMN yang go-publik. saham BUMN merupakan saham yang paling likuid dan berkapitalisasi pasar besar sehingga cenderung mendominasi pergerakan IHSG, yang berarti juga mendominasi harga saham secara keseluruhan. Saham BUMN merupakan saham Blue Chip nya pemerintah, yang berada dibawah kekuasaan pemerintah dan diyakini penulis sebagai saham yang tentunya paling sensitive terkait hal- hal di bidang pemerintahan, seperti berita, kebijakan, dan peraturan presiden.

Pengukuran yang digunakan antara lain Abnormal return (digunakan untuk memastikan apakah ada pengaruh informasi/berita politik terhadap adanya pengumuman terpilihnya kembali Presiden Jokowi pada pemilu periode 2019-2024 dan abnormal trading volume activity untuk melihat dan membandingkan apakah volume trading saham berbeda sebelum dan sesudah peristiwa. Abnormal dapat menunjukkan kejutan dalam aspek kejadian yang berpotensi besar mempengaruhi pergerakan harga saham. Untuk melihat adanya abnormalitas pada peristiwa, penelitian menggunakan metode study event, yaitu penelitian yang dilakukan dengan cara mempelajari reaksi pasar terhadap suatu peristiwa yang informasinya dipublikasikan sebagai suatu pengumuman dengan mengambil sampel berupa harga saham, volume, dan jumlah saham beredar dalam periode waktu penelitian 14 hari sebelum dan 14 hari sesudah peristiwa pengumuman kemenangan Presiden 22 Mei 2019 berdasarkan hasil keputusan KPU pada Pemilu 2019-2024.

Penelitian Ananto (2014) peristiwa pemilu leglislatif tidak berpengaruh signifikan terhadap abnormal return akan tetapi berpengaruh signifikan terhadap trading volume activity, hal ini mengindikasikan bahwa pemilu legislative mempengaruhi trading volume activity saham perusahaan, akan tetapi investor belum mendapatkan keuntungan yang diharapkan, karena adanya gejolak harga yang tidak bisa diprediksi sebelumnya. Penelitian Sundari (2009) menunjukan bahwa pelaksanaan pemilu 9 April 2009 tidak memberikan pengaruh yang kuat terhadap pergerakan harga saham disekitar maupun diluar pelaksanaan pemilu.

\section{Tujuan Penelitian}

Tujuan Penelitian ini adalah ntuk mengetahui dan membuktikan secara teori adanya reaksi Pasar Modal, dengan terdapatnya perbedaan: 
1. abnormal return saham

2. abnormal trading volume activity

Pada periode sebelum dan setelah peristiwa pengumuman kemenangan Presiden Jokowi periode yang kedua dalam pemilihan umum 2019-2029 (pada saham BUMN yang terdaftar di BEI).

\section{TINJAUAN PUSTAKA}

\section{Teori Efisiensi Pasar}

Konsep efisiensi pasar membahas tentang hubungan antara harga atau nilai sekuritas dengan informasi, bagaimana pasar bereaksi terhadap informasi-informasi, dan sejauh mana informasi dapat mempengaruhi pergerakan harga saham yang terbentuk (Hanafi, 2004). Bursa Efek Indonesia mengacu pada teori efisiensi pasar bentuk setengah kuat (Jogiyanto, 2010) karena Bursa Efek Indonesia adalah pasar yang nilai atau harga sekuritasnya secara penuh mencerminkan semua informasi yang dipublikasikan perusahaan dan terpengaruh oleh informasi/isu dan peristiwa yang diberitakan.

\section{Teori Asimetri Informasi}

Asimetri informasi merupakan kondisi ketidakseimbangan perolehan informasi antara pihak manajemen (prepaper) dengan pihak pemegang saham dan stakeholder (user). Pihak tertentu mempunyai informasi mengenai prospek dan resiko perusahaan yang lebih baik dibandingkan dengan pihak lainnya.

\section{Teori Event Study}

Studi peristiwa (event study) merupakan studi yang mempelajari reaksi pasar terhadap suatu peristiwa (event) yang informasinya dipublikasikan sebagai suatu pengumuman. Event study dapat digunakan untuk menguji kandungan informasi (information content) dari suatu pengumuman dan dapat juga digunakan untuk menguji efisiensi pasar bentuk setengah kuat (Jogiyanto, 2010).

\section{Return Saham}

Pengembalian (return) atas investasi merupakan hasil yang diperoleh dari suatu investasi, dihitung berdasarkan data historis. Dalam melakukan investasi investor dihadapkan pada ketidakpastian antara return yang akan diperoleh dengan risiko yang akan dihadapi (Herlianto, 2010:65-66).

\section{Expected Return}

Expected Return adalah keuntungan yang diharapkan oleh seorang investor dikemudian hari terhadap sejumlah dana yang telah ditempatkannya (Fahmi, 2011:174).

\section{Abnormal Return}

Hasil yang tidak sesuai harapan/abnormal karena adanya ringkasan tentang hasil yang sesungguhnya (return saham) berbeda dengan return yang diharapkan (expected return).

\section{Trading Volume Activity (TVA)}

Trading volume activity (volume perdagangan saham) yaitu indikator yang digunakan untuk mengukur likuiditas suatu saham. Apabila secara statistic perdagangan saham beberapa hari setelah peristiwa terdapat peningkatan dibanding beberapa hari sebelum peristiwa, maka dapat dikatakan bahwa terdapat peningkatan likuiditas perdagangan saham setelah terjadinya suatu peristiwa.

\section{Periode Estimasi}

Periode estimasi merupakan periode sebelum periode peristiwa, dan merupakan periode hari yang dilibatkan sebelum tanggal peristiwa untuk mengetahui menetapkan return ekspektasi dari rata-rata return harian.

\section{Periode Pengamatan}


Periode pengamatan atau jendela peristiwa (event window). Periode jendela sabagai periode pengamatan merupakan periode yang akan dihitung nilai abnormal return dan abnormal TVA.

\title{
Penelitian Terdahulu
}

Stesia J. Liogu, Ivonne S. Saerang, dan Joubert B. Maramis (2015) dalam penelitian Reaksi Pasar Modal Terhadap Pengumuman Kenaikan Harga BBM Atas Saham Lq 45 Pada Tanggal 1 November 2014 menemukan bahwa Pasar bereaksi terhadap Pengumuman Kenaikan Harga BBM atas Saham LQ45 dengan hasil Abnormal return yang signifikan, Trading volume activity yang signifikan dan Kapitalisasi Pasar yang signifikan.

Ni Nengah Sureni Yuniarthi dan I Ketut Sujana (2016) dalam penelitian Reaksi Pasar Modal Terhadap Pencalonan Jokowi Menjadi Presiden Republik Indonesia menemukan bahwa Peristiwa pelantikan Joko Widodo sebagai Presiden Republik Indonesia ke-7 tidak mengandung kandungan informasi yang berarti bagi investor sehingga membuat pasar tidak bereaksi.

Gede Bhakti Pratama, Ni Kadek Sinarwati \& Nyoman Ari Surya Dharmawan (2015) dalam penelitian Reaksi Pasar Modal Indonesia Terhadap Peristiwa Politik (Event study pada Peristiwa Pelantikan Joko Widodo Sebagai Presiden Republik Indonesia Ke-7) menemukan bahwa Peristiwa pelantikan Joko Widodo sebagai Presiden Republik Indonesia ke-7 tidak mengandung kandungan informasi yang berarti bagi investor sehingga membuat pasar tidak bereaksi.

\section{Model Penelitian}

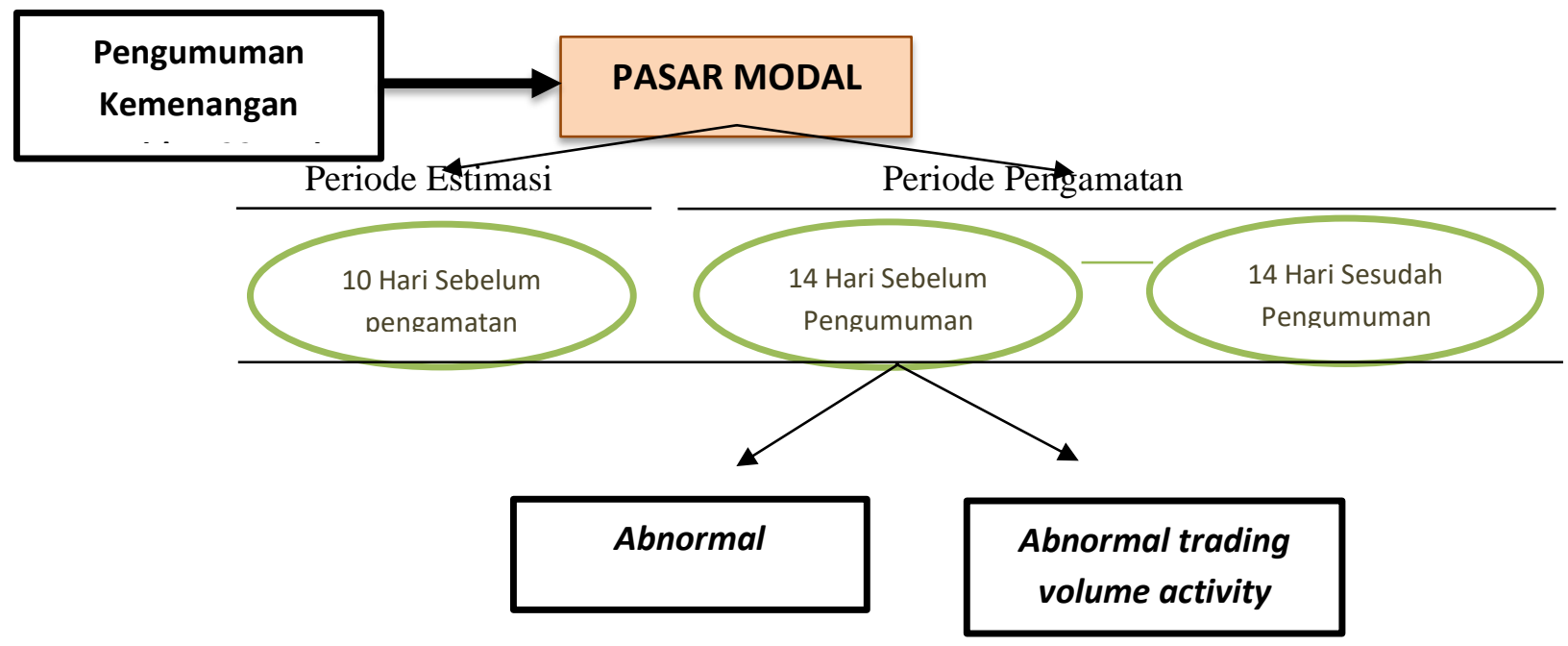

\author{
Gambar 1.Kerangka Pemikiran \\ Sumber : Kajian Teori, 2019
}

\section{Hipotesis Penelitian}

Pasar Modal dapat bereaksi terhadap peristiwa yang mengandung informasi penting, bersifat baru, dan berpotensi mempengaruhi keputusan Investor. Oleh karena itu, diduga terdapat perbedaan abnormal return setelah adanya peristiwa pengumuman kemenangan Presiden, dan diduga terdapat perbedaan abnormal trading volume activity setelah adanya peristiwa pengumuman kemenangan Presiden pada 22 Mei 2019. 


\section{METODE PENELITIAN}

\section{Pendekatan Penelitian}

Jenis penelitian adalah Komparatif, yaitu untuk menguji adanya perbedaan yang terjadi antar beberapa variabel atau indikator, dengan menggunakan metode Kuantitatif berupa data harga saham, volume dan jumlah saham beredar pada perusahaan BUMN yang terdaftar di BEI, sebanyak periode yang dibutuhkan dalam penelitian.

\section{Populasi, Sampel, dan Teknik Sampling}

Semua anggota populasi yaitu perusahaan BUMN yang terdaftar dalam Bursa Efek Indonesia periode terbaru 2019 menurut kementrian BUMN (sumber: bumn.go.id). Pengambilan sampel menggunakan metode Sampling Jenuh (sensus), yaitu menggunakan semua anggota populasi sebagai sampel. Besarnya sampel (seluruh anggota populasi) yang digunakan pada studi ini, ditetapkan sebanyak 20 saham perusahaan BUMN.

\section{Jenis dan Sumber Data}

Jenis data yang digunakan adalah data rasio yang mempunyai nilai nol mutlak. Sumber data yang digunakan adalah data sekunder, melalui situs web Indonesia Stock Exchange (untuk mengumpulkan data jumlah saham beredar) dan Yahoo Finance (untuk mengumpulkan data harga saham dan volume).

\section{Teknik Pengumpulan Data}

Penelitian Pustaka terhadap jurnal, literatur dan buku dilakukan untuk mempelajari teori-teori berhubungan. Kemudian, Penelitian Dokumenter dilakukan dengan mengunduh dan mengumpulkan data Perusahaan BUMN di BEI setiap harinya selama periode penelitian, dengan cara mengakses web.

\section{Definisi Operasional Variabel}

1. Return saham dihitung dengan rumus : $\quad \mathrm{R}=\frac{\mathrm{Pt}-\left(\mathrm{Pt}_{-1}\right)}{\left(\mathrm{Pt}_{-1}\right)}$

Keterangan :

$\mathrm{R} \quad=$ tingkat pengembalian (return) saham

$\mathrm{Pt}=$ harga saham pada periode $\mathrm{t}$

Pt-1 = harga saham pada periode t-1 (sebelumnya)

2. Expected Return dihitung dengan rumus : $\mathrm{ER}=\frac{\sum \mathrm{y}}{\mathrm{N}}$

Keterangan :

$\mathrm{y}=$ return rata-rata (Hari -25 sampai -15$)$

$\mathrm{N}=$ jumlah periode pengamatan

3. Abnormal Return dihitung dengan rumus : Abnormal Return $=$ Expected Return - Return Saham

Keterangan :

Expected Return = Return yang diharapkan

Return Saham = Return realisasi/ return yang sesungguhnya

4. TVA dihitung dengan rumus : TVA $=\frac{\text { Jumlah saham diperdagangkan }}{\text { Jumlah saham beredar }}$

5. Expected TVA di hitung dengan rumus: Expected TVA $=\frac{\sum \mathrm{TVA}}{\mathrm{N}}$

6. Abnormal TVA dihitung dengan rumus: Abnormal TVA $=$ Expected TVA - Actual TVA

7. Periode Estimasi:

Diambil dari 10 hari sebelum periode pengamatan, yaitu hari -25 sampai hari -15 untuk menghitung return realisasi dan return ekspektasi.

8. Periode Pengamatan 
Yaitu periode hari sebelum (-14 sampai -1) dan hari sesudah (1 sampai 14) pengumuman kemenangan, yang akan dibandingkan untuk melihat apabila terdapat perbedaan abnormal return dan trading volume activity yang signifikan.

\section{Teknik Analisis Data}

Uji-t Berpasangan (Paired sample t-test), yaitu metode pengujian hipotesis menggunakan data tidak bebas atau dependen (berpasangan) pada dua kasus yang berpasangan yaitu satu individu (objek penelitian) dikenai 2 buah perlakuan yang berbeda (sebelum peristiwa dan sesudah peristiwa).

\section{Hasil Uji Beda}

\section{HASIL PENELITIAN DAN PEMBAHASAN}

Tabel 1

Uji Beda Paired Samples Test AR \& ATVA Gabungan

\begin{tabular}{|c|c|c|c|c|c|c|c|c|c|}
\hline & & \multicolumn{5}{|c|}{ Paired Differences } & \multirow[b]{3}{*}{$\mathrm{t}$} & \multirow[b]{3}{*}{ Df } & \multirow{3}{*}{$\begin{array}{l}\text { Sig. }(2- \\
\text { tailed) }\end{array}$} \\
\hline & & \multirow[b]{2}{*}{ Mean } & \multirow{2}{*}{$\begin{array}{c}\text { Std. } \\
\text { Deviation } \\
\end{array}$} & \multirow{2}{*}{$\begin{array}{l}\text { Std. Error } \\
\text { Mean }\end{array}$} & \multicolumn{2}{|c|}{$\begin{array}{l}\text { 95\% Confidence } \\
\text { Interval of the } \\
\text { Difference }\end{array}$} & & & \\
\hline & & & & & Lower & Upper & & & \\
\hline $\begin{array}{l}\text { Pair } \\
1\end{array}$ & $\begin{array}{l}\text { AR Gabungan (H-) } \\
\text { AR Gabungan }(\mathrm{H}+)\end{array}$ & .01840 & .05026 & .00300 & .01249 & .02432 & 6.128 & 279 & .000 \\
\hline $\begin{array}{l}\text { Pair } \\
2\end{array}$ & $\begin{array}{l}\text { ATVA Gabungan }(\mathrm{H}-) \\
\text { ATVAGabungan }(\mathrm{H}+)\end{array}$ & -.00114 & .00941 & .00056 & .00225 & -.00003 & -2.029 & 279 & .043 \\
\hline
\end{tabular}

Sumber : Olah Data SPSS

T-hitung untuk abnormal return gabungan adalah 6,128 dengan probabilitas 0,000. Oleh karena itu nilai $-\mathrm{p}$ AR gabungan $0,000<0.05$. T-hitung untuk abnormal TVA gabungan adalah 2,029 dengan probabilitas 0,043 . Oleh karena itu nilai -p ATVA gabungan $0,043<0,05$.

\section{Hasil Hipotesis}

Berdasarkan hasil analisis yang didapatkan, maka hipotesis diterima. Penerimaan hipotesis dapat dijawab sebagai berikut:

1. Terdapat perbedaan abnormal return setelah adanya peristiwa pengumuman kemenangan Presiden.

2. Terdapat perbedaan abnormal trading volume activity terhadap adanya peristiwa pengumuman kemenangan Presiden.

Didapati hasil perbedaan yang signifikan pada abnormal return dan juga abnormal TVA, yang menyatakan bahwa Pasar Modal bereaksi terhadap peristiwa 22 Mei 2019, pengumuman kemenangan Presiden Jokowi.

\section{Pembahasan}

Berdasarkan rekapitulasi data Hasil Analisis Abnormal return, hasil analisis Paired Sample T-Test pada program SPSS memperlihatkan hasil yang signifikan berbeda pada perbandingan Abnormal return sebelum terhadap Abnormal return sesudah Peristiwa Pengumuman Kemenangan Presiden Jokowi. Berdasarkan teori analisis Periode Jendela 14 hari (sebelum vs sesudah), terdapat 9 hari yang mengalami perbedaan signifikan dan 5 hari yang tidak signifikan, dan hasil uji AR Gabungan memperlihatkan terdapat perbedaan yang signifikan, artinya ada reaksi yang timbul dari segi tingkat pengembalian investasi.

Berdasarkan rekapitulasi data Hasil Analisis Abnormal TVA, hasil analisis Paired Sample T-Test pada program SPSS memperlihatkan hasil yang tidak signifikan berbeda pada perbandingan Abnormal TVA sebelum terhadap Abnormal TVA sesudah Pengumuman. Berdasarkan teori analisis Periode Jendela 14 hari (sebelum vs sesudah), 14 hari didapati tidak terjadi perbedaan yang signifikan, akan tetapi bertolak belakang dengan uji ATVA 
gabungan yang memperlihatkan ternyata ada perbedaan signifikan (hampir tidak signifikan), hal ini menunjukan bahwa peristiwa pengumuman kemenangan berimbas juga ke aktivitas perdagangan investor yang fluktuasinya sangat kecil secara harian, sehingga hampir tidak terlihat munculnya reaksi, yang sesungguhnya reaksi itu ada.

Berdasarkan Teori Efisiensi Pasar dari sudut informasi, Pasar Modal Indonesia termasuk dalam pasar bentuk setengah kuat, dimana nilai atau fluktuasi harga saham masih terpengaruh dengan situasi ekonomi maupun nonekonomi (politik, keamanan, dll). Berdasarkan Teori Efisiensi Pasar dari sudut keputusan, Pasar Modal Indonesia termasuk dalam kriteria Pasar yang Efisien, dimana perubahan harga saham didasarkan informasi yang tersedia dan muncul di pasar dan berhubungan, akan mereaksikan pergeseran harga yang baru. Investor bereaksi dengan menggunakan informasi secara penuh dan cepat, sehingga harga sekuritas berubah semestinya. Kondisi ini dapat disebut dengan kondisi pasar efisien (Jogiyanto, 2013:547).

Secara statistik, pengujian data parsial (perbandingan hari sebelum dan sesudah, satu per satu) pada Aktivitas Perdagangan Investor (TVA) hanya menggambarkan sebuah kondisi tanpa memperhatikan kondisi secara keseluruhan yang memiliki saling keterkaitan dalam uji sampel berpasangan, hasil yang diperlihatkan adalah 'Tidak Signifikan'. Dalam Uji Gabungan, data disatukan, sehingga diperoleh hasil keseluruhan data yang berelasi satu sama lain, yang tidak terlihat dalam pengujian parsial, yaitu, ternyata 'Signifikan', artinya terdapat aktivitas perdagangan abnormal yang berbeda setelah adanya peristiwa (bereaksi). Secara teori, hal ini menunjukan adanya reaksi dari pasar modal terhadap peristiwa/informasi Pengumuman Kemenangan Presiden Jokowi 22 Mei 2019 dari segi volume perdagangan, yang tak dapat dirasakan secara harian, akan tetapi dapat terlihat perbedaan signifikannya setelah akumulasi hari.

Pernyataan ini didukung oleh Teori Asymetri Informasi, dimana Investor pada Saham BUMN percaya akan informasi yang dipegangnya yaitu 'nilai' yang terkandung dalam saham BUMN itu sendiri. Saham BUMN berkapitalisasi pasar besar, liquid dan merupakan saham penggerak IHSG, bukan terpengaruh fluktuasi pasar. Fluktuasi tetap ada, tapi tak akan terlalu bergejolak tajam seperti yang terjadi pada saham gorengan/murah. Oleh karena itu. Investor pemegang saham BUMN percaya nilai saham BUMN cukup kuat untuk menjaganya kembali stabil. Investor berharap gejolak politik yang terjadi hanya sentimen jangka pendek saja.

Meskipun Investor saham BUMN pada umumnya kalem dalam mengambil keputusan bertransaksi, tidak menutup kemungkinan bahwa tidak semua investor saham BUMN tidak akan terpengaruh jika muncul informasi yang diprediksi memberikan dampak pada keseluruhan saham, ditambah lagi, dalam transaksi saham BUMN, terdapat juga trader yang terlibat. Sehingga dalam uji Abnormal TVA gabungan, aktivitas kecil dari beberapa Investor saham BUMN yang panik, serta aktivitas trader dapat terlihat, sehingga terdapat perbedaan yang signifikan pada rata-rata aktivitas perdagangan Investor.

\section{PENUTUP}

\section{Kesimpulan}

Pada rata-rata Abnormal return saham sebelum dan sesudah Pengumuman 22 Mei 2019, terdapat perbedaan yang signifikan. Hal ini terbukti dengan hasil abnormal return yang tidak signifikan dengan nilai sig yang lebih besar dari nilai $\alpha$. Sesuai dengan hasil analisis, teori efisiensi pasar bentuk setengah kuat menjelaskan bahwa suatu informasi dapat mempengaruhi psikologi investor, sehingga dari hasil penelitian ini menunjukkan Pasar Modal Indonesia bereaksi terhadap peristiwa Pengumuman Kemenangan Presiden Jokowi 22 Mei 2019 berdasarkan keputusan KPU pada Pemilu 2019-2024.

Dalam Teori Efisiensi pasar, disebutkan bahwa pasar bereaksi terhadap informasi. Berdasarkan Teori Efisiensi Pasar dari sudut keputusan, Pasar Modal Indonesia termasuk dalam kriteria Pasar yang Efisien, dimana perubahan harga saham didasarkan informasi yang tersedia dan muncul di pasar dan berhubungan, akan mereaksikan pergeseran harga yang baru. Investor bereaksi dengan menggunakan informasi secara penuh dan cepat, sehingga harga sekuritas berubah dengan semestinya. Jika Pasar bereaksi dengan cepat membentuk harga yang baru, kondisi pasar dapat disebut dengan pasar efisien (Jogiyanto, 2013:547). Berdasarkan Teori Efisiensi Pasar dari sudut informasi, Pasar Modal Indonesia termasuk dalam pasar bentuk setengah kuat, dimana nilai atau harga sekuritasnya mencerminkan seluruh informasi yang tersedia termasuk laporan keuangan. Berkaitan dengan informasi, dalam pasar dengan bentuk ini, investor mengambil keputusan berdasarkan informasi, baik laporan 
keuangan maupun peristiwa yang terjadi. Berbeda dengan pasar bentuk kuat, dimana bahkan tersedia seluruh informasi pribadi/rahasia yang memastikan investor pasti mendapatkan keuntungan abnormal dan kurang terpengaruh dengan informasi, dalam pasar bentuk setengah kuat ini, ada kemungkinan bagi investor untuk memperoleh keuntungan abnormal (ataupun juga tidak) dari prediksi maupun impulsive buying/selling dari adanya suatu informasi, peristiwa dan pengumuman yang terjadi.

Pada rata-rata Abnormal TVA saham sebelum dan sesudah Pengumuman 22 Mei 2019, tidak terdapat perbedaan yang signifikan secara parsial (reaksi abnormal yang tidak terlihat secara harian), namun pergerakannya tampak dapat akumulasi hari. ATVA merupakan indikator pengujian yang teliti karena mengamati adanya aktivitas abnormal dari perbedaan aktivitas perdagangan yang tidak terlihat mempengaruhi aktivitas investor pada saham BUMN secara harian, sehingga aktivitas abnormal yang sangat sedikit itu hanya dapat terlihat perbedaan signifikannya dalam penggabungan hari.

Didukung oleh Teori Asymetri Informasi, Investor pemegang saham BUMN percaya pada value saham BUMN. Tipe value investor pada saham BUMN juga tidak menutup kemungkinan ada juga investor panik dan trader yang terpengaruh dengan berbagai pertimbangan mengambil keputusan, menyebabkan munculnya transaksi abnormal yang terdorong dari adanya informasi, yaitu Pengumuman Presiden $22 \mathrm{Mei}$, dan juga disebabkan oleh peristiwa-peristiwa penguat yang turut meramaikan peristiwa $22 \mathrm{Mei}$, sehingga beberapa (sebagian kecil) aktivitas investor menjadi tidak sesuai harapan (abnormal), oleh karena itu, meskipun perbandingan antara hari per hari tidak menunjukan adanya perbedaan abnormal, hasil gabungan hari memperlihatkan bahwa sebenarnya perbedaan itu abnormal. Perdagangan abnormal menunjukkan bahwa Pasar Modal Indonesia bereaksi terhadap pengumuman kemenangan.

\section{Saran}

Pasar modal Indonesia masih mudah terpengaruh dengan adanya pemberitaan atau informasi berkaitan dengan politik, ekonomi, keamanan, dan aspek-aspek dalam negara. Pengaruh tersebut berdampak pada fluktuasi harga saham. Akan tetapi, peminimalan dampak dari media dan pemberitaan terhadap investasi dapat diminimalisir oleh Investor dengan memilih saham-saham bernilai dan berkapitalisasi pasar besar, karena saham-saham dengan value yang baik tidak begitu mendapat pengaruh dari adanya informasi jangka pendek.

Penulis berharap agar penelitian ini dapat bermanfaat bagi para pelaku Pasar Modal Indonesia, terkhususnya Investor untuk menganalisis saham dari nilai yang terkandung dalam saham itu sendiri. Sebab saham yang likuid dan berkapitalisasi dan memiliki value, akan bermanfaat bagi Investor dalam jangka panjang dan tidak terlalu berfluktuasi kasar saat terjadi Peristiwa jangka pendek. Saham yang likuid memiliki kemampuan untuk kembali stabil.

Penulis mengapresiasi Pemerintah, serta badan hukum dan keamanan yang optimis bekerja menetralisir situasi dan menenangkan masyarakat untuk tidak takut menghadapi ancaman, dengan dasar bahwa ketakutan hanya akan membatasi langkah untuk maju. Dibandingkan khawatir dan panik, pemerintah menebar semangat positif agar masyarakat dan Investor optimis untuk harapan-harapan yang akan diwujudkan bersama menciptakan Indonesia yang lebih maju, yang tentu akan diikuti dengan perekonomian yang lebih stabil.

Data yang diperlukan dalam penelitian ini yaitu harga saham harian, dapat dicari di http://finance.yahoo.com, volume dan Listed Share (harga saham beredar), dapat dicari di http://idx.co.id. Penulis menyarankan penulis melengkapi data 1 saham dulu sampai menemukan hasil Abnormal return dan Abnormal TVA. Apabila cara pengumpulan data sudah efektif, data yang dikumpulkan sudah tepat dan sesuai tujuan, barulah lanjutkan mengumpulkan sejumlah data selanjutnya dengan tahapan yang telah dilakukan pada pengumpulan data 1 saham percobaan, agar tidak terjadi pemborosan waktu dalam pengumpulan data dan percobaan olah data. Karena yang menjadi hambatan penulis dalam mengumpulkan data adalah ketika semua data selesai dikumpulkan dan masih ada yang kurang, misalnya kesalahan penentuan jumlah hari dan tanggal periode penelitian (periode estimasi, periode pengujian, dan peristiwa), penulis kembali mengumpul dan mengolah ulang data dari awal untuk keseluruhan saham, hal tersebut membuat penulis banyak memakan waktu dalam pembuatan skripsi. Oleh karena itu, berdasarkan pengalaman ini penulis berharap peneliti selanjutnya tidak mengalami permasalahan yang sama.

Penulis berharap penelitian lanjutan dapat dibuat dalam disertasi/skripsi tersendiri yang dengan mengangkat analisa secara lebih mendalam, membahas khusus 'dampak dari reaksi pasar modal' secara spesifik dan mendetail 
serta 'temuan dibalik hari reaksi pasar modal (dampak)' dapat disertai grafik/chart aktivitas investor secara spesifik dalam 1 saham atau lebih yang diuji dalam suatu periode penelitian.

\section{DAFTAR PUSTAKA}

Aluy, C. A., Tulung, Joy Elly, \& Tasik, H. H. (2017). Pengaruh Keberadaan Wanita Dalam Manajemen Puncak Dan Kepemilikan Manajerial Terhadap Kinerja Keuangan Perbankan (Studi Pada Bank Bumn dan Bank Swasta Nasional Devisa di Indonesia). Jurnal Riset Ekonomi, Manajemen, Bisnis Dan Akuntansi, Vol. 5(2).

Ananto, D. (2014). Pengaruh Pemilu Legislatif Terhadap Abnormal return dan Trading volume activity Saham Di Jakarta Islamic Index (Studi Kasus Pada Peristiwa Pemilu Legislatif 09 April 2014). Jurnal Bisnis. Universitas Islam Negeri Kalijaga Yogyakarta. Hal 1-88.

Fahmi, I. (2011). Manajemen Risiko. Bandung: Alfabeta.

Fauzi, A. (2018). Peran Analisis Kredit Terhadap NPL pada PT. X. . Jurnal Manajemen Bisnis Dan Inovasi (JMBI) UNSRAT Vol. 5 No. 2

Hanafi, M. (2004). Manajemen Keuangan. Yogyakarta: BPFE UGM Sundari, V. (2009). Reaksi Pasar Modal Indonesia Atas Pelaksanaan Pemilihan Umum 9 april2009 Pada Bursa Efek Indonesia. Skripsi. Hal 1-9 Universitas Guna Darma. Jakarta.

Herlianto, D. (2010). Seluk beluk investasi di pasar modal Indonesia. Yogyakarta : Goysen Publishing.

Harga dan Volume Saham https://idx.co.id diakses pada Juni - Juli 2019

Jumlah Saham Beredar https://yahoo.finance.co.id diakses pada Juni - Juli 2019

Jogiyanto, H. (2010). Studi Peristiwa: Menguji Reaksi Pasar Modal Akibat Suatu Peristiwa. Edisi Pertama. Yogyakarta: BPFE.

Jogiyanto, H. (2013). Teori Portofolio dan Analisis Investasi Edisi Kedelapan. Yogyakarta : BPFE.

Liogu, S.J., Saerang, I.S., dan Maramis, J.B. (2015). Reaksi Pasar Modal Terhadap Pengumuman Kenaikan Harga BBM Atas Saham Lq 45 Pada Tanggal 1 November 2014. Jurnal EMBA. vol.3. no.1. pp 1274-1282. Universitas Sam Ratulangi Manado.

Pratama, G. B., Sinarwati, N. K., dan Dharmawan N. S. (2015). Reaksi Pasar Modal Indonesia Terhadap Peristiwa Politik (Event Study pada Peristiwa Pelantikan Joko Widodo Sebagai Presiden Republik Indonesia Ke-7). Jurnal Akuntansi. vol. 3. no.13. pp 1-11.

Yuniarthi, N. S., dan Sujana, I. K. (2016). Reaksi Pasar Modal Terhadap Pencalonan Jokowi Menjadi Presiden Republik Indonesia. Jurnal Akuntansi. vol.16. no.2. pp 1-27.

Tulung, J. E., Saerang, I. S., \& Pandia, S. (2018). The influence of corporate governance on the intellectual capital disclosure: a study on Indonesian private banks. Banks and Bank Systems, 13(4), 61-72.

Tulung, J. E., \& Ramdani, D. (2018). Independence, size and performance of the board: An emerging market research. Corporate Ownership \& Control, 15(2-1), 201-208. 